JPDN ISSN 2579-6461 (Online) ISSN 2460-6324 (Print)

Jurnal Pendidikan Dasar Nusantara

Volume 5 | Nomor 2 | Januari 2020|

DOI: https://doi.org/DOI 10.29407/jpdn.v5i2.13554

\title{
ANALISIS BENTUK KEDISIPLINAN SISWA DALAM MENGIKUTI KEGIATAN BELAJAR DENGAN MOTIVASI BELAJAR SISWA KELAS IV SDN I GONDOSULI GONDANG
}

\author{
Fitria Nindy Lestari'1), Wisda Miftakhul'Ulum²), \\ fitrianindy03@gmail.com,wisda@stkippgritulungagung.ac.id \\ Pendidikan Guru Sekolah Dasar \\ STKIP PGRI Tulungagagung \\ No Handphone: +6281222232128
}

\begin{abstract}
Abstrak: Kedisiplinan merupakan hal yang berhubungan dengan motivasi. Motivasi sangat diperlukan untuk menumbuhkan sikap disiplin siswa. Siswa-siswi kelas IV SDN I Gondosuli mengalami permasalahan yang mempengaruhi proses belajar dan motivasi belajar siswa. Kurangnya disiplin siswa dalam melakukan pembelajaran saat guru sedang menjelaskan materi, siswa yang sibuk sendiri dan tidak memperhatikan penjelasan guru. Tujuan penelitian ini adalah mendiskripsikan kedisiplinan siswa dalam kegiatan belajar dan mendiskripsikan motivasi siswa dalam belajar di kelas IV SDN I Gondosuli. Jenis penelitian ini adalah penelitian kualitatif menggunakan metode fenomenologi. Teknik pengumpulan data angket, observasi, wawancara dan dokumentasi. Teknik analisis data yang digunakan adalah reduksi data, penyajian data dan Penarikan kesimpulan. Hasil penelitian menunjukkan bahwa bentuk kedisiplian siswa dalam kegiatan belajar dari angket, wawancara dan observasi terdapat 10 butir soal pengamatan ada 2 soal terendah dalam kegiatan belajarnya menunjukkan tingkatan kedisiplinan yang tinggi. Motivasi belajarnya terdapat 10 butir soal pengamatan ada 4 soal rendah dalam motivasi belajar siswa cenderung rendah pada kegiatan belajar, diantaranya mengenai siswa gugup ketika berpendapat didepan kelas, sikap siswa masih pasif dalam bertanya jawab dan kurang percaya diri dengan jawabannya. Berdasarkan hasil penelitian dapat disimpulkan bahwa bentuk kedisiplinan siswa dalam kegiatan belajar menunjukkan hasil kriteria tinggi dan motivasi belajar siswa menunjukkan kriteria cenderung rendah.
\end{abstract}

Kata Kunci: Bentuk kedisiplinan, Kegiatan belajar, Motivasi belajar

\section{ANALYSIS OF STUDENT'S DISCIPLINARY FORM IN FOLLOWING LEARNING ACTIVITIES WITH LEARNING MOTIVATION IN CLASS IV STUDENTS OF SDN I GONDOSULI GONDANG}

Abstract: Discipline is a matter related to motivation. Motivation is needed to foster student discipline. Students in grade IV SDN I Gondosuli experienced problems that affected the learning process and student motivation. Lack of student discipline in 


\section{Fitria, Wisda, Analisis Nilai Kedisiplinan Siswa...}

learning when the teacher is explaining the material, students are busy themselves and do not pay attention to the teacher's explanation. The purpose of this study is to describe student discipline in learning activities and describe students' motivation in learning in class IV SDN I Gondosuli. This type of research is a qualitative study using the phenomenological method. Questionnaire data collection techniques, observations, interviews and documentation. Data analysis techniques used are data reduction, data presentation and conclusion drawing. The results showed that the form of student discipline in learning activities from questionnaires, interviews and observations there were 10 items of observation there were 2 lowest questions in learning activities showed a high level of discipline. Motivation to learn there are 10 items of observation there are 4 low questions in student motivation tend to be low in learning activities, including the students nervous when arguing in front of the class, the attitude of students is still passive in asking questions and lacking confidence in the answers. Based on the results of the study it can be concluded that the form of student discipline in learning activities shows the results of high criteria and student learning motivation shows the criteria tend to be low.

Keywords: Form of discipline, Learning activities, Motivation to learn

\section{PENDAHULUAN}

Kedisiplinan merupakan hal yang berhubungan dengan motivasi. Motivasi belajar dapat dikatakan sebagai dorongan pada diri. Kedisiplinan dan motivasi belajar penting untuk dimiliki oleh siswa. Sardiman (2014, hal.75) dalam kegiatan belajar, motivasi dapat dikatakan sebagai keseluruhan daya penggerak di dalam diri siswa yang menimbulkan kegiatan belajar, yang menjamin kelangsungan dari kegiatan belajar dan yang memberikan arahan pada kegiatan belajar, sehingga tujuan yang dikehendaki oleh subyek belajar itu dapat tercapai.

Siswa yang mempunyai disiplin dan motivasi belajar yang tinggi akan mempunyai keinginan dan melakukan kegiatan belajar lebih tekun untuk mencapai prestasi belajar yang diharapkan. Daryanto seperti dikutip (Jailani, 2014) bahwa faktor yang mempengaruhi kegiatan belajar siswa adalah faktor pesikologis (perhatian, minat, bakat, motivasi, kematangan dan kesiapan.Faktor eksternal adalah faktor yang berasal dari luar diri siswa terdiri dari lingkungan sekolah, teman, keluarga dan masyarakat.

Berdasarkan informasi yang diperoleh dari wawancara yang dilakukan pada tanggal 11 februari 2019 dengan guru sekolah dasar kelas IV di SDN I Gondosuli , diperoleh informasi bahwa terdapat beberapa permasalahan yang mempengaruhi proses 


\section{Fitria, Wisda, Analisis Nilai Kedisiplinan Siswa...}

belajar antara lain kedisiplinan belajar dan motivasi belajar siswa. Siswa kelas IV memiliki tingkat kedisiplinan yang berbeda- beda. Permasalahan selanjutnya terkait motivasi belajar siswa, berdasarkan wawancara dengan guru kelas IV motivasi belajar siswa diperoleh informasi ada beberapa siswa yang belum mempunyai motivasi pada belajar. Ada 5 siswa yang belum antusias dalam mengikuti kegiatan pembelajaran.

Guru memiliki peran aktif dalam menegendalikan berbagai perilaku yang tidak disiplin dan menanamkan kebiasaan siswa dengan perilaku yang disiplin. Meningkatkan anjuran atau perintah untuk mentaati berbagai peraturan serta memberi sanksi yang tegas bagi siswa yang melanggar kedisiplinan. Masalahnya siswa yang berasal dari latar belakang lingkungan keluarga yang berbeda sehingga pemahaman dan keputusan terhadap norma dan etika kedisiplinan tidak semuanya tertanam dengan baik dalam jiwa mereka, apalagi siswa yang kurang mendapat perhatian dan pendidikan kedisiplinan dari orang tuanya.

Disesuaikan dengan fakta di lapangan penelitian di sekolah SDN I Gondosuli menurut observasi awal peneliti menemukan fakta bahwa nilai kedisiplinan belajar siswa memiliki hubungan tentang motivasi belajar siswa yang dapat berpengaruh pada proses belajar siswa. Sesuai latar belakang maka penulis mengadakan penelitian dengan tujuan menganalisis bentuk kedisiplinan siswa dalam mengikuti kegiatan belajar dengan motivasi belajar siswa kelas IV SDN I Gondosuli Gondang““.

\section{METODE}

Jenis penelitian ini adalah fenomenologi dengan pendekatan kualitatif. Prosedur penelitian ini menggunakan tahap penelitian menurut Moleong (2016, hal.127) yaitu tahap pralapangan, tahap pekerjaan lapangan, dan tahap analisis data, tahap penulisan laporan. Subyek dalam penelitian ini adalah siswa-siswi kelas IV SDN 1 Gondosuli berjumlah 23 siswa. Terdiri dari 13 siswa laki-laki dan 10 siswa perempuan.waktu penelitian ini dilaksanakan pada tanggal 27 Maret sampai 27 April 2019. Lokasi penelitian ini di SDN 1 Gondosuli Kecamatan Gondang Kabupaten Tulungagung. Sugiono (2016,hal.222) mengatakan bahwa Instrumen merupakan alat yang digunakan oleh peneliti untuk mengumpulkan data. Instrumen merupakan alat yang digunakan oleh peneliti untuk mengumpulkan data. Instrumen pendukung dalam penelitian ini ada tiga macam yaitu : (1) Lembar Angket (2) Lembar Observasi (3) Pedoman Wawancara dan (4) Dokumen. Teknik pengumpulan data yang dilakukan oleh peneliti adalah 
Fitria, Wisda, Analisis Nilai Kedisiplinan Siswa...

melalui tiga metode, yaitu: (1) Angket (2) Observasi (3) Wawancara (4) Dokumentasi.

Tehnik analisis data menggunakan reduksi data, penyajian data dan Penarikan kesimpulan. Pengecekan keabsahan data menggunkan perpanjangan keikutsertaan, triangulasi tehnik dan triangulasi sumber.

\section{HASIL}

Tabel 4.2 Data Hasil Kedisiplinan Siswa dalam Kegiatan Belajar

\begin{tabular}{|c|c|c|c|c|c|c|c|c|c|c|c|c|c|c|c|c|c|c|c|c|c|c|c|}
\hline \multirow{2}{*}{\multicolumn{2}{|c|}{$\begin{array}{l}\text { Nama } \\
\text { Siswa }\end{array}$}} & \multicolumn{10}{|c|}{ Nomer Butir Kedisiplinan Angket } & \multirow{2}{*}{ Jumlah } & \multicolumn{10}{|c|}{ Nomer Butir Kedisiplinan Observasi } & \multirow{2}{*}{ Jumlah } \\
\hline & & 1 & 2 & 3 & 4 & 5 & 6 & 7 & 8 & 9 & 10 & & $\mathbf{l}$ & 2 & 3 & 4 & 5 & 6 & 7 & 8 & 9 & 10 & \\
\hline 1 & A.R.C & 1 & 0 & 1 & 1 & 1 & 1 & 0 & 1 & 1 & 1 & 8 & 1 & 1 & 0 & 1 & 1 & 1 & 1 & 1 & 0 & 1 & 8 \\
\hline 2 & A.S.A & 1 & 1 & 1 & 0 & 1 & 1 & 1 & 1 & 1 & 0 & 8 & 1 & 1 & 0 & 0 & 1 & 1 & 1 & 1 & 1 & 1 & 8 \\
\hline 3 & A.A.P & 1 & 1 & 0 & 1 & 0 & 1 & 0 & 1 & 1 & 1 & 7 & 1 & 1 & 0 & 1 & 1 & 0 & 1 & 1 & 0 & 1 & 7 \\
\hline 4 & D.D.R & 0 & 1 & 1 & 1 & 0 & 1 & 0 & 1 & 0 & 1 & 6 & 1 & 1 & 0 & 1 & 0 & 0 & 1 & 1 & 1 & 1 & 7 \\
\hline 5 & D.T.S & 1 & 1 & 1 & 1 & 0 & 1 & 1 & 1 & 1 & 1 & 9 & 1 & 1 & 1 & 1 & 0 & 1 & 1 & 1 & 1 & 1 & 9 \\
\hline 6 & H.F.A & 1 & 1 & 0 & 1 & 1 & 1 & 0 & 1 & 1 & 1 & 8 & 1 & 1 & 1 & 0 & 1 & 0 & 1 & 1 & 1 & 1 & 8 \\
\hline 7 & J.A.L & 1 & 1 & 1 & 1 & 1 & 1 & 1 & 0 & 1 & 1 & 9 & 1 & 1 & 1 & 1 & 1 & 1 & 1 & 1 & 0 & 1 & 9 \\
\hline 8 & J.E. $Z$ & 1 & 0 & 1 & 1 & 0 & 1 & 1 & 1 & 1 & 1 & 8 & 1 & 1 & 1 & 1 & 0 & 1 & 1 & 1 & 0 & 1 & 8 \\
\hline 9 & KK & 1 & 1 & 1 & 1 & 0 & 1 & 1 & 0 & 1 & 1 & 8 & 1 & 1 & 1 & 0 & 1 & 0 & 1 & 1 & 1 & 1 & 8 \\
\hline 10 & L.S.D & 1 & 0 & 1 & 0 & 1 & 1 & 1 & 0 & 0 & 1 & 6 & 1 & 1 & 0 & 1 & 0 & 1 & 1 & 1 & 0 & 1 & 7 \\
\hline 11 & L.P.P & 1 & 1 & 1 & 1 & 1 & 1 & 0 & 1 & 1 & 1 & 9 & 1 & 1 & 1 & 0 & 1 & 1 & 1 & 1 & 1 & 1 & 9 \\
\hline 12 & M.B.P & 1 & 1 & 0 & 1 & 0 & 1 & 1 & 1 & 1 & 1 & 8 & 1 & 1 & 0 & 1 & 0 & 1 & 1 & 1 & 1 & 1 & 8 \\
\hline 13 & R.N.A & 1 & 1 & 0 & 1 & 1 & 1 & 1 & 0 & 1 & 1 & 8 & 1 & 1 & 1 & 0 & 1 & 0 & 1 & 1 & 1 & 1 & 8 \\
\hline 14 & R.H & 1 & 1 & 0 & 0 & 1 & 1 & 1 & 1 & 1 & 1 & 8 & 1 & 1 & 1 & 1 & 0 & 1 & 1 & 1 & 0 & 1 & 8 \\
\hline 15 & R.M & 0 & 1 & 1 & 1 & 1 & 1 & 0 & 1 & 1 & 1 & 8 & 1 & 1 & 0 & 1 & 0 & 1 & 1 & 1 & 1 & 1 & 8 \\
\hline 16 & R.M.A & 1 & 1 & 0 & 1 & 0 & 1 & 1 & 1 & 1 & 1 & 8 & 1 & 1 & 1 & 0 & 1 & 1 & 1 & 1 & 0 & 1 & 8 \\
\hline 17 & S.P & 1 & 1 & 0 & 1 & 0 & 1 & 1 & 0 & 1 & 1 & 7 & 1 & 1 & 0 & 1 & 0 & 0 & 1 & 1 & 0 & 1 & 6 \\
\hline 18 & S.C.P & 1 & 1 & 1 & 1 & 0 & 1 & 1 & 1 & 1 & 1 & 9 & 1 & 1 & 1 & 1 & 1 & 0 & 1 & 1 & 1 & 1 & 9 \\
\hline 19 & S.M.I & 1 & 1 & 0 & 1 & 0 & 1 & 1 & 1 & 1 & 1 & 8 & 1 & 1 & 0 & 1 & 1 & 0 & 1 & 1 & 1 & 1 & 8 \\
\hline 20 & S.A.T & 1 & 1 & 0 & 1 & 1 & 1 & 1 & 1 & 1 & 1 & 9 & 1 & 1 & 1 & 1 & 1 & 0 & 1 & 1 & 1 & 1 & 9 \\
\hline 21 & T.P.R & 1 & 0 & 0 & 1 & 1 & 1 & 1 & 1 & 1 & 1 & 8 & 1 & 1 & 0 & 1 & 1 & 1 & 0 & 1 & 1 & 1 & 8 \\
\hline 22 & Z.S & 1 & 1 & 1 & 1 & 0 & 1 & 1 & 0 & 1 & 1 & 8 & 1 & 1 & 0 & 1 & 1 & 1 & 0 & 1 & 1 & 1 & 8 \\
\hline 23 & A.L & 1 & 1 & 0 & 1 & 0 & 1 & 1 & 1 & 0 & 1 & 7 & 1 & 1 & 1 & 1 & 0 & 1 & 0 & 1 & 0 & 1 & 7 \\
\hline & mlah & 21 & 19 & 12 & 20 & 11 & 23 & 17 & 17 & 20 & 22 & 182 & 23 & 23 & 12 & 17 & 14 & 14 & 20 & 23 & 14 & 23 & 183 \\
\hline
\end{tabular}

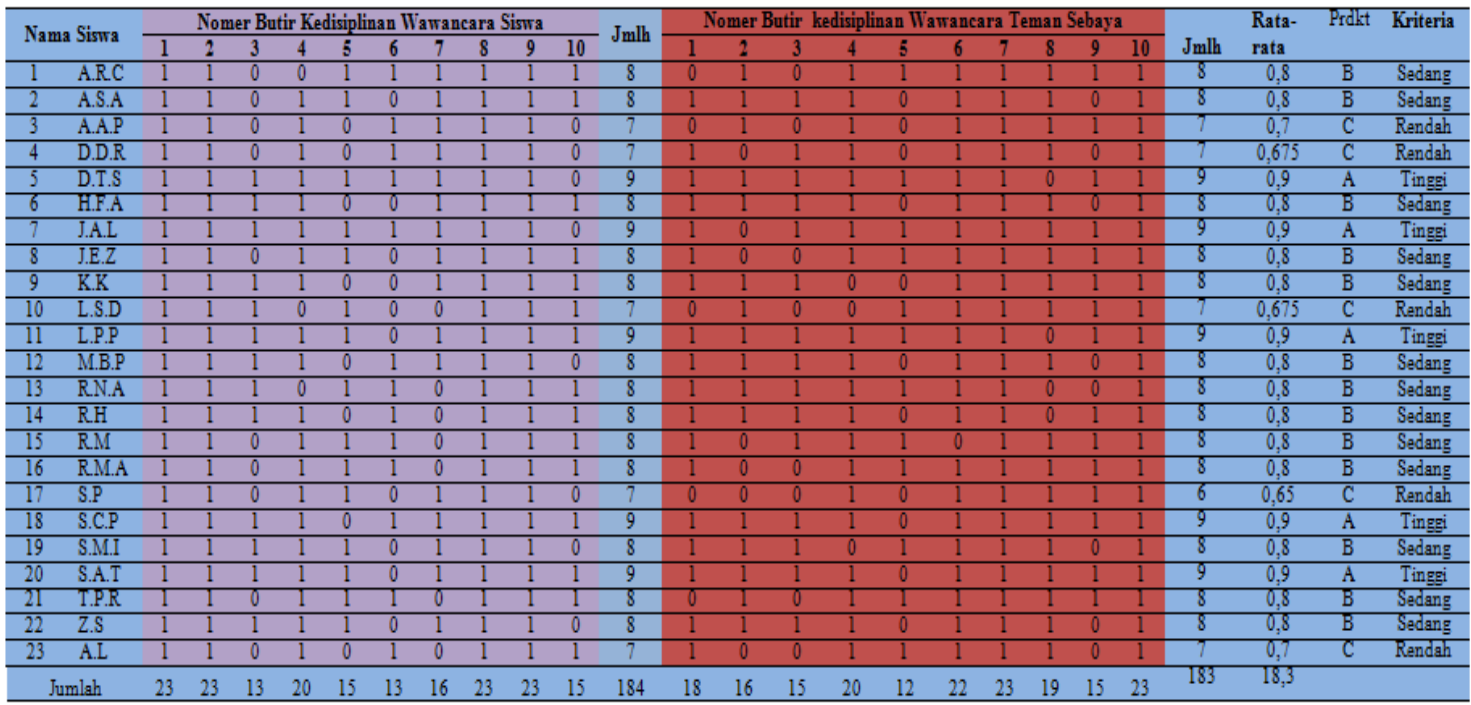

\section{Keterangan:}

Angket

: Observasi

Wawancara siswa

Wawancara Teman Sebaya
1 = Jawaban ya pada butir soal

$0=$ Jawaban tidak Pada Butir soal 
Fitria, Wisda, Analisis Nilai Kedisiplinan Siswa...

Berdasarkan tabel 4.2 diatas, diperoleh data hasil penelitian mengenai bentuk kedisiplinan siswa dalam kegiatan belajar siswa dari 23 siswa peringkat teratas yaitu, terdapat 5 siswa berada pada kriteria tinggi yaitu dengan rata - rata 9, 13 siswa berada pada kriteria sedang yaitu dengan rata - rata 8, dan 5 siswa berada pada kritera rendah dengan rata - rata 6.

\section{Tabel 4.3 Data Hasil Motivasi belajar siswa}

\begin{tabular}{|c|c|c|c|c|c|c|c|c|c|c|c|c|c|c|c|c|c|c|c|c|c|c|c|}
\hline \multirow{2}{*}{\multicolumn{2}{|c|}{$\begin{array}{l}\text { Nama } \\
\text { Siswa }\end{array}$}} & \multicolumn{10}{|c|}{ Nomer Butir Motivasi Angket } & \multirow{2}{*}{ Jumlah } & \multicolumn{10}{|c|}{ Nomer Butir Motivasi Observasi } & \multirow{2}{*}{ Jumlah } \\
\hline & & 1 & 2 & 3 & 4 & 5 & 6 & 7 & 8 & 9 & 10 & & 1 & 2 & 3 & 4 & 5 & 6 & 7 & 8 & 9 & 10 & \\
\hline 1 & A.R.C & 1 & 1 & 0 & 1 & 1 & 1 & 1 & 1 & 1 & 0 & 8 & 1 & 1 & 1 & 0 & 1 & 1 & 1 & 0 & 1 & 1 & 8 \\
\hline 2 & A.S.A & 1 & 1 & 1 & 0 & 1 & 1 & 1 & 0 & 1 & 0 & 7 & 1 & 1 & 1 & 0 & 1 & 1 & 0 & 1 & 0 & 1 & 7 \\
\hline 3 & A.A.P & 1 & 1 & 1 & 0 & 1 & 1 & 1 & 0 & 1 & 0 & 7 & 1 & 1 & 0 & 1 & 1 & 1 & 0 & 1 & 0 & 1 & 7 \\
\hline 4 & D.D.R & 0 & 1 & 1 & 1 & 1 & 1 & 0 & 0 & 1 & 0 & 6 & 1 & 1 & 0 & 1 & 0 & 1 & 1 & 0 & 1 & 1 & 7 \\
\hline 5 & D.T.S & 1 & 1 & 1 & 1 & 1 & 1 & 0 & 1 & 1 & 1 & 9 & 1 & 1 & 1 & 1 & 0 & 1 & 1 & 1 & 1 & 1 & 9 \\
\hline 6 & H.F.A & 1 & 1 & 1 & 1 & 1 & 1 & 1 & 0 & 1 & 0 & 8 & 1 & 1 & 1 & 1 & 1 & 1 & 0 & 1 & 0 & 1 & 8 \\
\hline 7 & J.A.L & 1 & 1 & 1 & 0 & 1 & 1 & 1 & 1 & 1 & 1 & 9 & 1 & 1 & 0 & 1 & 1 & 1 & 1 & 1 & 1 & 1 & 9 \\
\hline 8 & J.E.Z & 1 & 1 & 1 & 0 & 1 & 1 & 0 & 1 & 1 & 1 & 8 & 1 & 1 & 0 & 1 & 1 & 1 & 1 & 0 & 1 & 1 & 8 \\
\hline 9 & KK & 1 & 1 & 1 & 1 & 1 & 1 & 1 & 0 & 1 & 0 & 8 & 1 & 1 & 1 & 1 & 0 & 1 & 0 & 1 & 1 & 1 & 8 \\
\hline 10 & L.S.D & 0 & 1 & 1 & 1 & 1 & 1 & 1 & 0 & 1 & 0 & 7 & 1 & 0 & 1 & 0 & 1 & 1 & 0 & 1 & 1 & 1 & 7 \\
\hline 11 & L.P.P & 1 & 1 & 1 & 1 & 1 & 1 & 1 & 0 & 1 & 1 & 9 & 1 & 1 & 1 & 1 & 1 & 1 & 0 & 1 & 1 & 1 & 9 \\
\hline 12 & M.B.P & 1 & 1 & 1 & 0 & 1 & 1 & 1 & 1 & 1 & 0 & 8 & 1 & 1 & 1 & 1 & 0 & 1 & 1 & 0 & 1 & 1 & 8 \\
\hline 13 & R.N.A & 0 & 1 & 1 & 1 & 1 & 1 & 1 & 0 & 1 & 1 & 8 & 1 & 1 & 0 & 1 & 0 & 1 & 1 & 1 & 1 & 1 & 8 \\
\hline 14 & R.H & 1 & 1 & 1 & 0 & 1 & 1 & 1 & 1 & 1 & 0 & 8 & 1 & 0 & 1 & 0 & 1 & 1 & 1 & 1 & 1 & 1 & 8 \\
\hline 15 & R.M & 0 & 1 & 1 & 1 & 1 & 1 & 1 & 1 & 0 & 1 & 8 & 1 & 1 & 1 & 1 & 0 & 1 & 1 & 1 & 0 & 1 & 8 \\
\hline 16 & R.M.A & 0 & 1 & 1 & 1 & 1 & 1 & 1 & 1 & 0 & 1 & 8 & 1 & 1 & 1 & 0 & 1 & 1 & 0 & 1 & 1 & 1 & 8 \\
\hline 17 & S.P & 0 & 1 & 1 & 1 & 1 & 1 & 1 & 1 & 0 & 1 & 8 & 1 & 1 & 1 & 1 & 0 & 1 & 0 & 1 & 1 & 1 & 8 \\
\hline 18 & S.C.P & 1 & 1 & 0 & 1 & 1 & 1 & 1 & 1 & 1 & 1 & 9 & 1 & 1 & 1 & 1 & 1 & 1 & 0 & 1 & 1 & 1 & 9 \\
\hline 19 & S.M.I & 1 & 1 & 1 & 0 & 1 & 1 & 1 & 0 & 1 & 1 & 8 & 1 & 1 & 0 & 1 & 0 & 1 & 1 & 1 & 1 & 1 & 8 \\
\hline 20 & S.A.T & 1 & 1 & 1 & 1 & 1 & 1 & 1 & 1 & 1 & 0 & 9 & 1 & 1 & 0 & 1 & 1 & 1 & 1 & 1 & 1 & 1 & 9 \\
\hline 21 & T.P.R & 1 & 1 & 1 & 0 & 1 & 1 & 1 & 0 & 1 & 1 & 8 & 1 & 1 & 1 & 0 & 1 & 0 & 1 & 1 & 1 & 1 & 8 \\
\hline 22 & Z.S & 1 & 1 & 1 & 0 & 1 & 1 & 0 & 1 & 1 & 1 & 8 & 1 & 1 & 0 & 1 & 1 & 0 & 1 & 1 & 1 & 1 & 8 \\
\hline 23 & A.L & 0 & 1 & 1 & 0 & 1 & 1 & 1 & 0 & 1 & 0 & 6 & 1 & 0 & 1 & 1 & 1 & 0 & 1 & 1 & 0 & 1 & 7 \\
\hline Jun & lah & 16 & 21 & 18 & 14 & 23 & 23 & 20 & 14 & 20 & 12 & 181 & 23 & 19 & 15 & 17 & 15 & 20 & 14 & 19 & 18 & 23 & 183 \\
\hline
\end{tabular}

\begin{tabular}{|c|c|c|c|c|c|c|c|c|c|c|c|c|c|c|c|c|c|c|c|c|c|c|c|c|c|}
\hline \multirow{2}{*}{ Nama Siswa } & \multicolumn{10}{|c|}{ Nomer Butir Motivasi Wawancara Siswa } & \multirow{2}{*}{ Jmlh } & \multicolumn{10}{|c|}{ Nomer Butir Motivasi Wamancara Teman Sebaya } & \multirow[b]{2}{*}{ Jmlh } & \multirow{2}{*}{$\begin{array}{l}\text { Rata- } \\
\text { rata }\end{array}$} & \multirow[t]{2}{*}{ Predkt } & \multirow[t]{2}{*}{ Kriteria } \\
\hline & 1 & 2 & 3 & 4 & 5 & 6 & 7 & 8 & 9 & 10 & & 1 & 2 & 3 & 4 & 5 & 6 & 7 & 8 & 9 & 10 & & & & \\
\hline $1 \mathrm{~A} \cdot \mathrm{RC}$ & 1 & 1 & 1 & 1 & 0 & 1 & 0 & 1 & 1 & 1 & 8 & 1 & $\mathrm{~T}$ & 1 & 0 & 1 & 1 & 1 & 1 & 0 & 1 & 8 & 0,8 & B & Sedang \\
\hline 2 A.S.A & 1 & l & 0 & 1 & 0 & 1 & 1 & I & 0 & 1 & 7 & 1 & T & 0 & 1 & 0 & $\mathrm{~T}$ & 1 & $\mathrm{~T}$ & 0 & $\overline{1}$ & 7 & 0,7 & $\mathrm{C}$ & Rendah \\
\hline 3 A.A.P & 1 & 1 & 0 & 1 & 1 & 1 & 0 & 1 & 0 & 1 & 7 & 1 & 1 & 1 & 1 & 0 & 0 & 1 & 1 & 0 & 1 & 7 & 0,7 & $\mathrm{C}$ & Rendah \\
\hline $\begin{array}{ll}4 & \text { D.D.R }\end{array}$ & 1 & 1 & 0 & 1 & 1 & 1 & 0 & T & 0 & 1 & 7 & 1 & 1 & 0 & 0 & 0 & $\mathrm{~T}$ & 7 & 7 & 1 & 1 & 7 & 0,675 & $\mathrm{C}$ & Rendah \\
\hline 5 D.T.S & 1 & 1 & 1 & 1 & 1 & 1 & 1 & 1 & 0 & 1 & 9 & 1 & 1 & 1 & 0 & 1 & 1 & 1 & 1 & 1 & 1 & 9 & 0,9 & A & Tinggi \\
\hline $\begin{array}{ll}6 & \text { H.F.A }\end{array}$ & 1 & 1 & 1 & $\mathrm{l}$ & 0 & 1 & 0 & I & 1 & 1 & 8 & 1 & $\mathrm{~T}$ & 0 & 1 & 1 & $\mathrm{l}$ & 1 & 1 & 0 & $\overline{1}$ & 8 & 0,8 & B & Sedang \\
\hline $\begin{array}{ll}7 & \text { J.A.L }\end{array}$ & 1 & 1 & 0 & 1 & $\mathrm{l}$ & $\mathrm{l}$ & $\mathrm{l}$ & 1 & $\mathrm{l}$ & 1 & 9 & 1 & 1 & $\mathrm{~T}$ & $\mathrm{l}$ & $\mathrm{I}$ & 0 & 1 & 1 & 1 & 1 & 9 & 0,9 & A & Tinggi \\
\hline 8 J.E.Z & 1 & 1 & 1 & 1 & 0 & 1 & 1 & 1 & 0 & 1 & 8 & 1 & 1 & 0 & 1 & 0 & 1 & 1 & 1 & 1 & 1 & 8 & 0,8 & $B$ & Sedang \\
\hline $\begin{array}{ll}9 & \text { K.K } \\
\end{array}$ & 1 & 1 & 1 & 1 & 0 & 1 & 1 & 1 & 0 & 1 & 8 & 1 & 1 & 1 & 0 & 1 & 1 & 1 & 1 & 0 & 1 & 8 & 0,8 & $B$ & Sedang \\
\hline $\begin{array}{ll}10 & \text { L.S.D } \\
\end{array}$ & 1 & 1 & 0 & 1 & 0 & 1 & 1 & 1 & 0 & 1 & 7 & 1 & 1 & 0 & 1 & 1 & 0 & 1 & 1 & 0 & 1 & 7 & 0,7 & $\mathrm{C}$ & Sedang \\
\hline 11 L.P.P & 1 & 1 & 0 & 1 & 1 & 1 & 1 & 1 & 1 & 1 & 9 & 1 & 1 & 1 & 1 & 0 & 1 & 1 & 1 & 1 & 1 & 9 & 0,9 & A & Tinggi \\
\hline 12 M.B.P & 1 & 1 & 1 & 1 & 1 & 1 & 0 & 1 & 0 & 1 & 8 & 1 & 1 & 1 & 0 & 1 & 0 & 1 & 1 & 1 & 1 & 8 & 0,8 & B & Sedang \\
\hline 13 R.A.A & 1 & 1 & 1 & 1 & 0 & 1 & 1 & 1 & 0 & 1 & 8 & 1 & 0 & 0 & 1 & 1 & 1 & 1 & 1 & 1 & 1 & 8 & 0,8 & B & Sedang \\
\hline 14 R.H & 1 & 1 & 1 & 1 & 0 & 1 & 1 & 1 & 0 & 1 & 8 & 1 & 1 & 1 & 1 & 1 & 0 & 1 & 1 & 0 & 1 & 8 & 0,8 & B & Sedang \\
\hline $\begin{array}{ll}15 & \mathrm{RM} \\
\end{array}$ & 1 & 1 & 1 & 1 & 0 & 1 & 1 & 1 & 0 & 1 & 8 & 1 & 1 & 1 & 0 & 1 & 1 & 1 & 1 & 0 & 1 & 8 & 0,8 & $B$ & Sedang \\
\hline 16 R.M.A & 1 & 1 & 1 & 1 & 0 & 1 & 0 & 1 & 1 & 1 & 8 & 1 & 1 & 1 & 1 & 1 & 0 & 1 & 1 & 0 & 1 & 8 & 0,8 & B & Sedang \\
\hline $17 \quad$ S.P & 1 & 1 & 1 & 1 & 0 & 1 & 1 & 1 & 0 & 1 & 8 & 1 & 0 & 0 & 1 & 1 & 1 & 1 & 1 & 1 & 1 & 8 & 0,8 & $B$ & Sedang \\
\hline 18 S.C.P & 1 & 1 & 1 & 1 & 1 & 1 & 0 & 1 & 1 & 1 & 9 & 1 & 1 & 1 & 0 & 1 & 1 & 1 & 1 & 1 & 1 & 9 & 0,9 & A & Tinggi \\
\hline 19 S.M.I & 1 & 1 & 1 & 1 & 1 & 1 & 0 & 1 & 0 & 1 & 8 & 1 & 1 & 0 & 1 & 0 & 1 & 1 & 1 & 1 & 1 & 8 & 0,8 & $B$ & Sedang \\
\hline 20 S.A.T & 1 & 1 & 1 & 1 & 0 & 1 & 1 & 1 & 1 & 1 & 9 & 1 & 1 & 1 & 0 & 1 & 1 & 1 & 1 & 1 & 1 & 9 & 0,9 & $\mathrm{~A}$ & Tinggi \\
\hline $\begin{array}{ll}21 & \text { T.P.R } \\
\end{array}$ & 1 & 1 & 0 & 1 & 0 & 1 & 1 & 1 & 1 & 1 & 8 & 1 & 0 & 1 & 1 & 1 & 1 & 1 & 1 & 0 & 1 & 8 & 0,8 & $B$ & Sedang \\
\hline $\begin{array}{ll}22 & Z . S \\
\end{array}$ & 1 & 1 & 0 & 1 & 1 & 1 & 0 & 1 & 1 & 1 & 8 & 1 & 1 & 1 & 0 & 1 & 1 & 1 & 7 & 0 & 1 & 8 & 0,8 & $B$ & Sedang \\
\hline 23 A.L & 1 & 1 & 0 & 1 & 0 & 1 & 1 & 1 & 0 & 1 & 7 & 1 & 0 & 1 & 0 & 1 & 1 & 1 & 1 & 0 & 1 & 7 & 0,675 & $\mathrm{C}$ & Rendah \\
\hline Jumlah & 23 & 23 & 14 & 22 & 9 & 23 & 14 & 23 & 9 & 23 & 183 & 23 & 19 & 15 & 13 & 17 & 17 & 22 & 23 & $3 \quad 11$ & 23 & 183 & 18,3 & & \\
\hline
\end{tabular}

\section{Keterangan:}
: Angket
: Observasi
$1=$ Jawabanya pada butir soal
Wawancara siswa
$0=$ Jawaban tidak Pada Butir soal
Wawancara Teman Sebaya 
Fitria, Wisda, Analisis Nilai Kedisiplinan Siswa...

Berdasarkan Tabel 4.3 diatas, diperoleh data hasil penelitian mengenai motivasi belajar siswa dari 23 siswa peringkat teratas yaitu, terdapat 5 siswa berada pada kriteria tinggi dengan rata - rata 9, 13 siswa berada pada kriteria sedang dengan rata-rata 8, dan 5 siswa pada kriteria rendah dengan rata - rata 7.

Tabel 4.4 Wawancara Guru

\begin{tabular}{|c|c|c|}
\hline No & Pertanyaan & Jawaban Guru \\
\hline 1. & $\begin{array}{l}\text { Menurut ibu apa yang akan anda } \\
\text { lakukan ketika ada siswa yang } \\
\text { tidak memperhatikan anda saat } \\
\text { mengajar? }\end{array}$ & $\begin{array}{l}\text { Memberikan motivasi dan melakukan pendekatan } \\
\text { kepada siswa. }\end{array}$ \\
\hline 2. & $\begin{array}{l}\text { Bagaimana cara ibu sebagai guru } \\
\text { dalam mengajarkan siswa } \\
\text { menjadi pribadi yang memiliki } \\
\text { kedisiplinan pada belajarnya? }\end{array}$ & $\begin{array}{l}\text { Mengajarkan siswa memiliki kedisiplinan dengan } \\
\text { di mulai dari guru menyuruh siswa mentaati tata } \\
\text { tertib di sekolah (berpakaian rapi, membawa topi } \\
\text { ketika upacara, mengerjakan pr di rumah,). }\end{array}$ \\
\hline 3. & $\begin{array}{l}\text { Bagaimana cara ibu menarik } \\
\text { perhatian siswa kepada ibu saat } \\
\text { proses pembelajaran berlangsung } \\
\text { siswa mualai ramai? }\end{array}$ & $\begin{array}{l}\text { Ketika siswa mulai ramai di saat guru mengajar } \\
\text { guru biasanya memberikan pancingan soal, dan } \\
\text { menunjuk siswa yang ramai untuk mengerjakan } \\
\text { soal. }\end{array}$ \\
\hline 4. & $\begin{array}{l}\text { Bagaimana cara ibu mengatasi } \\
\text { jika murid ibu sudah mualai } \\
\text { jenuh dalam menerima proses } \\
\text { pembelajaran? }\end{array}$ & $\begin{array}{l}\text { Memberikan selingan dengan bernyanyi, di } \\
\text { kurikulum k13 kan banyak materi-materi untuk } \\
\text { menyanyi dan juga memberikan quis dan apresiasi } \\
\text { agar siswa tidak jenuh di dalam kelas. }\end{array}$ \\
\hline 5. & $\begin{array}{l}\text { Bagaimana upaya r ibu } \\
\text { mendisiplinkan siswa untuk } \\
\text { mengikuti kegiatan belajar di } \\
\text { kelas? }\end{array}$ & $\begin{array}{l}\text { Mendisipliinkan siswa untuk mengikuti kegiatan } \\
\text { belajar dengan menghargai orang lain di dalam } \\
\text { kelas dan mendengarkan guru yang sedang } \\
\text { berbicara dengan sikap yang respek. }\end{array}$ \\
\hline 6. & $\begin{array}{l}\text { Bagaimana cara ibu memotivasi } \\
\text { siswa ketika dia sudah bosan } \\
\text { dengan pembelajaran? }\end{array}$ & $\begin{array}{l}\text { Caranya dengan meminta siswa kerja kelompok } \\
\text { kemudian disuruh maju di depan kelas yang } \\
\text { nilainnya baik akan diberi hadiah. }\end{array}$ \\
\hline 7 & $\begin{array}{l}\text { Bagaimana cara ibu mengontrol } \\
\text { belajar siswa disekolah? }\end{array}$ & $\begin{array}{llr}\text { Selalu dikontrol contohnya anak yang sedang } \\
\text { pembelajarannya kurang konsentrasi maka } \\
\text { dibimbing dan berkeliling mengontrol setiap siswa. }\end{array}$ \\
\hline 8 & $\begin{array}{l}\text { Bagaimana ibu cara } \\
\text { menumbuhkan rasa percaya diri } \\
\text { kepada siswa? }\end{array}$ & $\begin{array}{l}\text { Menghadirkan proses belajar yang nyaman dan } \\
\text { menyenagkan bagi siswa memberikan } \\
\text { kesempatan kepada siswa untuk bisa } \\
\text { mengekspresikan pendapatnya di depan kelas bisa } \\
\text { membuat rasa percaya diri semakin } \\
\text { besar,membiasakan mengadakan kopetensi di kelas } \\
\text { seperti membaca puisis, membaca di depan , } \\
\text { bernyanyi dan menulis dipapan tulis karena itu bisa } \\
\text { membuat mereka lebih percaya diri. }\end{array}$ \\
\hline 9. & $\begin{array}{l}\text { Bagaimana cara anda } \\
\text { memberikan dorongan semangat } \\
\text { belajar dikelas? }\end{array}$ & $\begin{array}{l}\text { Diberi pengarahan, memberikan pekerjaan rumah } \\
\text { dan memotivasi siswa dalam segi agama }\end{array}$ \\
\hline 10. & $\begin{array}{l}\text { Menurut ibu penyebab yang } \\
\text { mempengaruhi motivasi belajar } \\
\text { siswa? }\end{array}$ & $\begin{array}{l}\text { Yang pertama itu dari diri siswaitu sendiri, yang } \\
\text { kedua dari keluarga yang kurang ada perhatian. }\end{array}$ \\
\hline
\end{tabular}


Fitria, Wisda, Analisis Nilai Kedisiplinan Siswa...

Sumber: Wawancara Guru Kelas IV

Bedasarkan Tabel 4.4 hasil wawancara dengan guru SD Negeri 1 Gondosuli secara keseluruhan guru telah menggunakan komponen yang ada didalam sistem pembelajaran. Respon siswa saat pembelajaran sangat bermacam meliputi aktif, pasif ramai sendiri. Strategi yang digunakan guru meliputi kooperatif, kontekstual, inquiri dan ekspositori. Metode yang digunakan guru meliputi ceramah, diskusi, pemberian tugas dan tanya jawab. Melalui hasil wawancara tersebut guru mengungkapkan bahwa kedisiplinan belajar mempunyai peranan penting dalam mendukung kelancaran belajar disekolah.

\section{PEMBAHASAN}

Mendiskripsikan Kedisiplinan siswa dalam kegiatan belajar

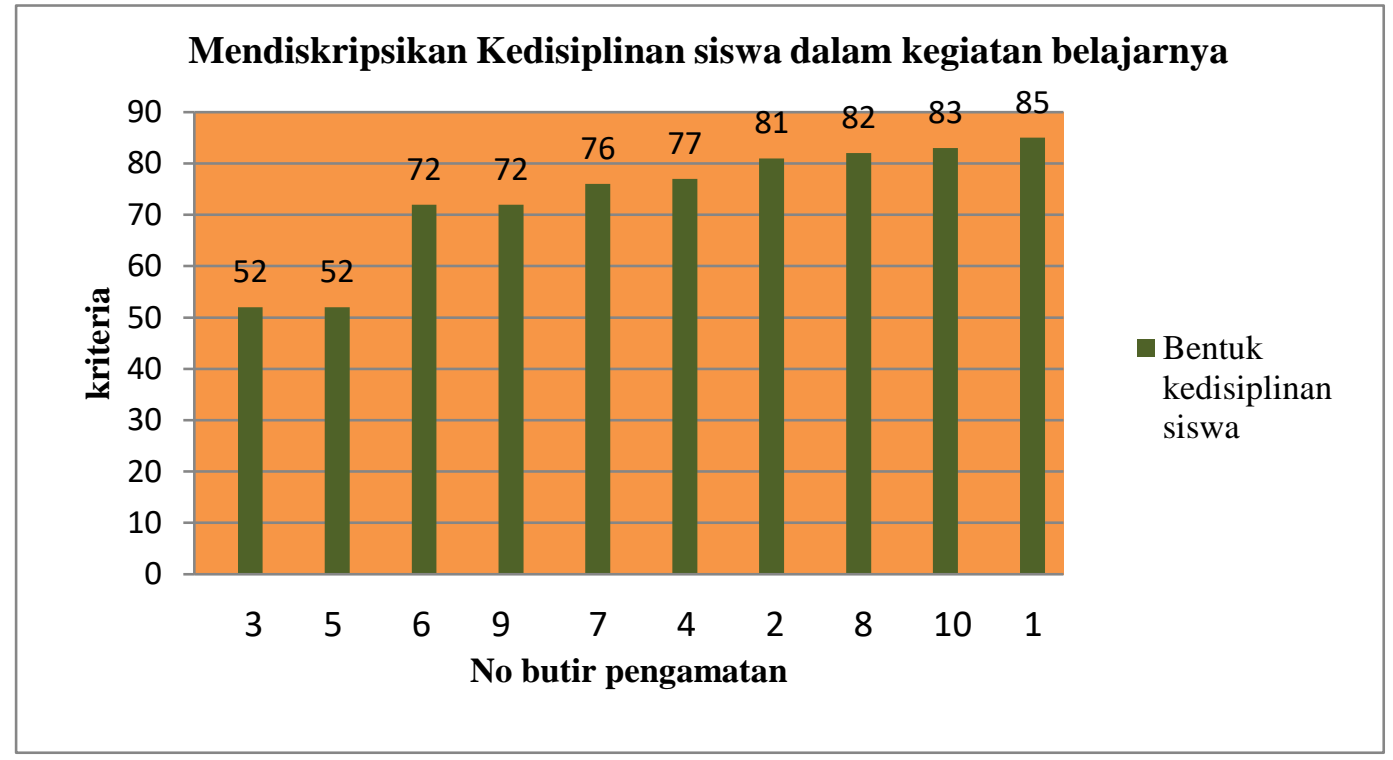

Grafik 4.1 Mendiskripsikan Kedisiplin Siswa yang Sering Dilakukan dalam Kegiatan Belajarnya

Berdasarkan grafik 4.1 diatas menjelaskan bahwa tingkatan sikap kedisiplinan siswa pada kegiatan belajar di kelas IV SD Negeri 1 Gondosuli dari angket, wawancara, dan hasil observasi. Grafik 4.1 juga menjelaskan nilai tiap butir pengamatan, nilai tertinggi terdapat dibutir pengamatan no $2,8,10,1$ pada butir pengamatan no 2 mengenai siswa memakai seragam dengan atribut lengkap. Butir pengamatan no 8 menegenai siswa mengumpulkan tugas tepat waktu ini menunjukkan bahwa siswa sudah memiliki kedisiplinan dalam kegiatan belajar dengan mengumpulkan tugas tepat waktu. Butir 
Fitria, Wisda, Analisis Nilai Kedisiplinan Siswa...

pengamatan no 10 dan 1 mengenai memperhatikan guru saat menjelaskan materi dengan sungguh-sungguh dan selalu tepat waktu dalam berangkat sekolah ini menunjukkan bahwa siswa kelas IV sudah memiliki sikap untuk taat terhadap kegiatan pembelajaran di sekolah.

Nilai sedang terdapat pada butir pengamatan no 6,9,7,4 pada butir pengamatan no 6 mengenai menyelesaikian tepat waktu soal-soal yang diberikan guru ketika pembelajaran, tidak semua siswa kelas IV disiplin dalam melaksanakan tugas yang menjadi tagung jawabnya 5 siswa yang tidak disiplin dalam menyelesaikan tugas tepat waktu. Butir pengamatan no 9 mengenai siswa di rumah hanya bermain dan tidak pernah belajar. Siswa kelas IV dalam disiplin belajar dirumah 5 siswa menjawab bermain dari pada belajar. Dari observasi yang peneliti temukan kebanyakan siswa lebih senang bermain game sehingga mereka lupa dengan belajarnya. Butir pengamatan no 7 mengenai siswa di rumah mempelajari kembali materi pelajaran yang guru berikan di sekolah.

\section{Mendiskripsikan Motivasi Belajar}

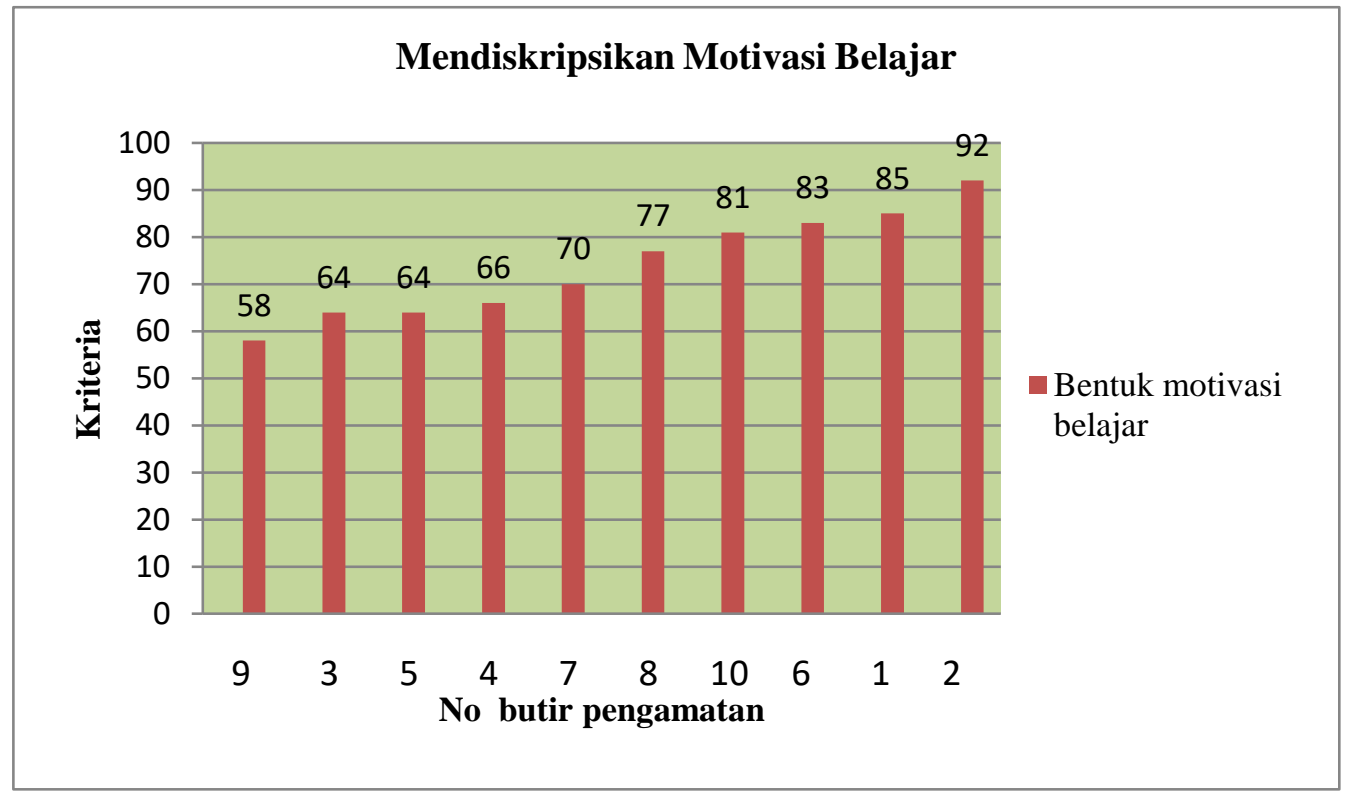

Grafik 4.2 Mendiskripsikan Motivasi Belajar Siswa Yang Sering Dilakukan

Berdasarkan grafik 4.2 Tingkat sikap motivasi siswa SD Negeri 1 Gondosuli dari angket, wawancara dan observasi. Grafik 4.1 juga menjelaskan nilai tiap butir pengamatan, nilai tinggi terdapat dibutir pengamatan no 10, 6, 1, 2. Pada butir pengamatan no 10 mengenai siswa tidak menyerah untuk mengerjakan soal latihan yang 
Fitria, Wisda, Analisis Nilai Kedisiplinan Siswa...

diberikan guru sampai bisa. Dalam butir soal ini siswa menunjukkan rasa ingin tahu dan tekun dalam mengerjakan tugas. Butir pengamatan no 6 mengenai siswa mengerjakan sugguh-sungguh pada saat guru memberikan tugas. Pada butir 1 dan 2 Saat guru memberikan tugas ,siswa percaya diri dengan jawaban siswa sendiri. Siswa kelas IV sudah ada dorongan dari dalam dirinya seperti percaya diri dengan jawabannya dan lebih senang bekerja mandiri.

Nilai sedang terdapat pada butir pengamatan no 7,8 pada butir pengamatan no 7 mengenai siswa senang mencari soal latihan dan mencoba mengerjakannya. Rata-rata siswa kelas IV menjawab tidak senang mencari soal latihan. Butir pengamatan no 8 mengenai siswa membaca materi sebelum materi tersebut disampaikan siswa tidak membacanya karena siswa lebih senang bermain dari pada membaca. Nilai rendah terdapat pada no 9,3,5,4,7 pada butir no 9 mengenai siswa ragu- ragu menjawab pertanyaan dari guru. Butir pengamatan no 3 mengenai siswa eggan menjawab pertanyaan tentang pelajaran yang diberikan guru, siswa kelas IV ada 5 siswa yang masih rendah dalam motivasi belajarnya dan sikap siswa masih pasif dalam bertanya jawab, tidak ada respon tentang pelajaran yang diberikan guru. Siswa kelas IV lebih baik diam dan tidak bertanya kepada guru tentang materi yang kurang dimengerti karena malu, dan takut salah sebelum mereka bertanya.

\section{Hubungan Kedisiplinan Siswa dengan Motivasi Belajar}

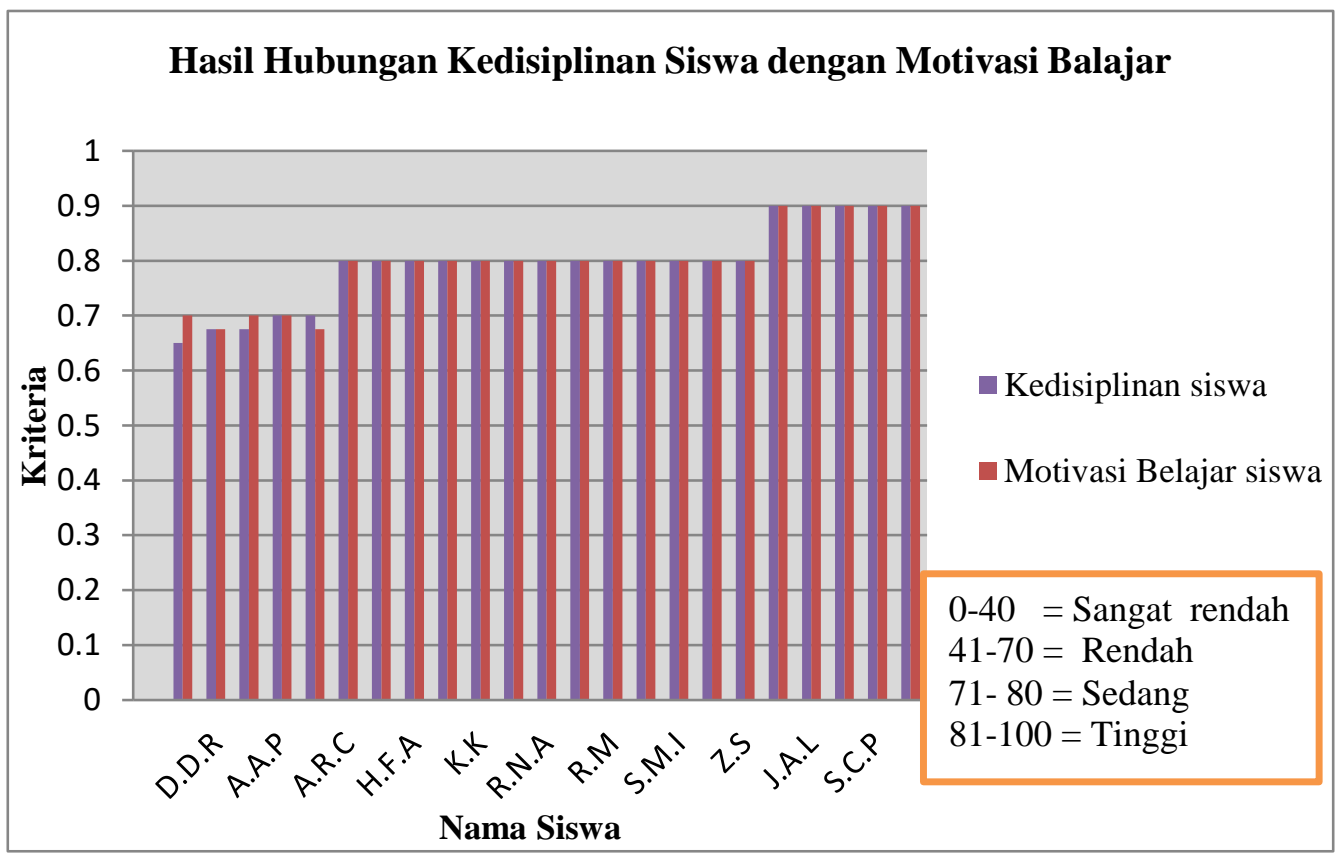

Grafik 4.3 Hasil Hubungan Kedisiplinan dengan motivasi belajar 
Fitria, Wisda, Analisis Nilai Kedisiplinan Siswa...

Berdasarkan grafik 4.3 diatas dapat menjelaskan bahwa kedisiplinan dalam kegiatan belajar siswa dengan motivasi belajar siswa ketika berada di kelas memiliki hubungan atau terkaitan dengan menunjukkan adanya kenaikan yang signifikan antara kedisiplinan siswa dari rendah ke tinggi begitu juga dengan motivasi belajar siswa dari rendah ke tinggi. Hal ini dilihat dari data yang menunjukkan ke linier, siswa yang memiliki kriteria tinggi dalam kedisiplinannya dia juga mendapatkan kriteria tinggi dalam motivasi belajar, siswa yang memiliki kriteria sedang dalam motivasi dia juga mendapatkan kriteria yang sedang juga di kedisiplinan belajarnya.

Siswa yang memiliki motivasi belajar yang tinggi akan mempunyai semangat dalam belajar. Siswa yang mempunyai dorongan pada dirinya untuk belajar, akan mempengaruhi prestasi belajar yang dicapainya. Siswa dengan semangat yang tinggi dan ketaatan dalam menaati segala peraturan, rajin masuk sekolah, rajin mengerjakan tugas, memperhatikan guru saat kegiatan pembelajaran, aktif dalam kegiatan belajar dikelas, tentunya akan memperoleh prestasi belajar yang tinggi pula. Jadi jika siswa mempunyai motivasi belajar dan disiplin belajar yang tinggi maka akan berpengaruh terhadap prestasi belajar siswa tersebut.

\section{Hubungan Kedisiplinan Siswa dengan Motivasi Intrinsik}

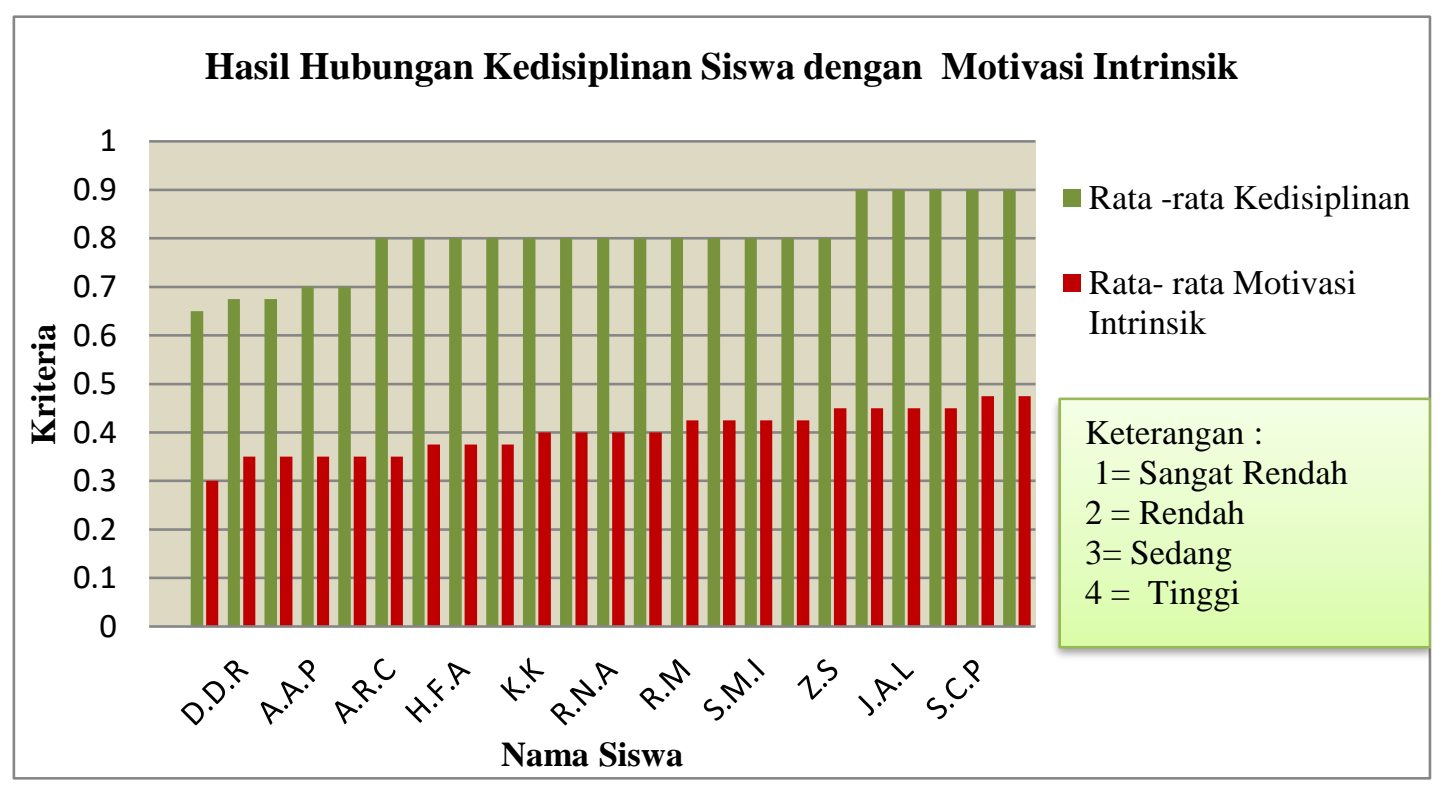

Grafik 4.4 Hasil Hubungan Kedisiplinan Siswa dengan Motivasi Intrinsik

Berdasarkan grafik 4.4 diatas menjelaskan kedisiplinan siswa pada motivasi intrinsik siswa kelas IV SD Negeri 1 Gondosuli memiliki hubungan atau keterkaitan 
Fitria, Wisda, Analisis Nilai Kedisiplinan Siswa...

dengan menunjukkan adanya kenaikan yang signifikan antara kedisiplinan siswa dari rendah ketinggi begitu juga dengan motivasi intrinsik siswa dari rendah ketinggi.

\section{Hubungan Kedisiplinan Siswa dengan Motivasi Ekstrinsik}

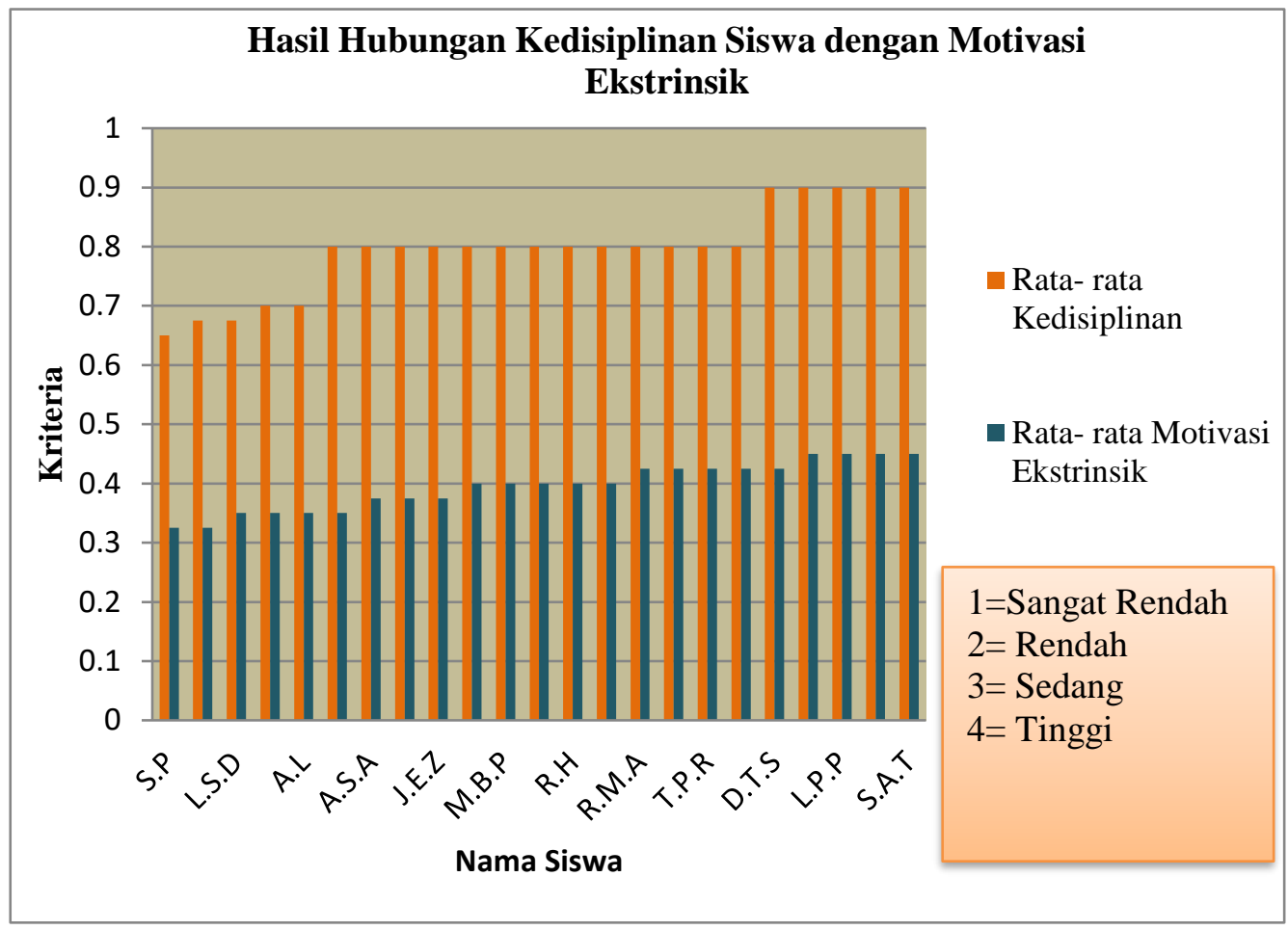

Grafik 4.5 Hasil Hubungan Kedisiplinan Siswa dengan Motivasi Ekstrinsik

Berdasarkan grafik 4.5 diatas menjelaskan kedisiplinan siswa pada motivasi ekstrinsik siswa kelas IV SD Negeri 1 Gondosuli memiliki hubungan atau keterkaitan dengan menunjukkan adanya kenaikan yang signifikan antara kedisiplinan siswa dari rendah ketinggi begitu juga dengan motivasi ekstrinsik siswa dari rendah ketinggi. Hal ini dilihat dari data yang menunjukkan linier, siswa yang memiliki kriteria tinggi dalam kedisiplinannya siswa juga mendapatkan kriteria tinggi dalam motivasi ekstrinsiknya.

Siswa dengan kriteria baik ini motivasi yang timbul karena pengaruh dari luar individu apakah karena ajakan atau suruhan atau paksaan dari orang lain sehingga dengan keadaan demikian seseorang mau melakukan sesuatu. Siswa SD Negeri 1 Gondosuli memiliki motivasi ekstrinsik sedang dan tinggi dalm belajarnya Dilihat dari grafik 4.5 Siswa yang kriteria sedang memiliki sikap tidak aktif dalam pembelajaran dan harus ada rangsangan dari luar seperti pemberian hadiah, pujian, tidak percaya diri dalam mengutarakan pendapatnya siswa hanya diam dan tidak merespon apa yang guru jelaskan. Sedangkan siswa kriteria tinggi memiliki sikap aktif dalam pembelajaran, 
Fitria, Wisda, Analisis Nilai Kedisiplinan Siswa...

dalam kegiatan pembelajaran baik diberikan rangsangan dari luar seperti hadiah maupun pujian siswa tetap aktif dalam pembelajaran yang guru berikan.

\section{KESIMPULAN}

1. Diskripsi kedisiplinan siswa kelas IV SDN 1 Gondosuli dalam kegiatan belajar menunjukkan tingkatan kedisiplinan yang tinggi.

2. Diskripsi Motivasi belajar siswa SDN I Gondosuli dalam kegiatan belajar menunjukkan tingkatan motivasi cenderung rendah.

3. Hubungan kedisiplinan dalam kegiatan belajar siswa dengan motivasi belajar siswa ketika berada di kelas memiliki hubungan atau terkaitan dengan menunjukkan adanya kenaikan yang signifikan antara kedisiplinan siswa dari rendah ke tinggi begitu juga dengan motivasi belajar siswa dari rendah ke tinggi.

4. Hubungan kedisiplinan siswa pada motivasi intrinsik siswa kelas IV SDN 1 Gondosuli memiliki hubungan atau keterkaitan dengan menunjukkan adanya kenaikan yang signifikan antara kedisiplinan siswa dari rendah ketinggi begitu juga dengan motivasi intrinsik siswa dari rendah ketinggi.

5. Hubungan kedisiplinan siswa pada motivasi ekstrinsik siswa kelas IV SD Negeri 1 Gondosuli memiliki hubungan atau keterkaitan dengan menunjukkan adanya kenaikan yang signifikan.

\section{DAFTAR RUJUKAN}

Sardiman. (2014). Interaksi dan Motivasi Belajar Mengajar. Jakarta: PT Raja Grafindo Persada.

Daryanto (2013.hal 50).Perkembangan Disiplin.Yogyakarta: Gava Media.

Sugiyono. (2016). Metode Penelitian Kuabtitatif, Kuaitatif, dan R\&D.

Bandung: Alfabeta. 